\title{
Major Factors Leading Rapid Urbanization in China and Pakistan: A Comparative Study
}

\author{
Naveed Malik \\ School of Public Affairs, University of Science and Technology of China, P.R. China \\ E-mail: nam@mail.ustc.edu.cn
}

Fahad Asmi

School of Public Affairs, University of Science and Technology of China, P.R. China E-mail: fasmie@mail.ustc.edu.cn

Madad Ali

School of Public Affairs, University of Science and Technology of China, P.R. China E-mail: ali12@mail.ustc.edu.cn

Md. Mashiur Rahman

School of Public Affairs, University of Science and Technology of China, P.R. China E-mail: mashiur@mail.ustc.edu.cn

Received: July 15, 2017 Accepted: August 14, 2017 Published: August 16, 2017

doi: 10.5296/jsss.v5i1.11710 URL: http://doi.org/10.5296/jsss.v5i1.11710

\begin{abstract}
The current document analyzed the statistical data for the year 2015 to make a comparative analysis in the case of China and Pakistan. The results conclude the migration and the refugee related challenge in Pakistan is the most critical factor to be observed and demands high level of attention. On the other side, the strengthening infrastructure in china is the massive pull factor to increase urbanization and economic growth. Moreover, the future lessons learnt from the China's progressive growth can improve the pace of urbanization in the neighboring
\end{abstract}


region like Pakistan. However, the china's economic growth is dominating by the industrialization trend as china can be labeled as World's factory. However, Pakistan's agricultural dependency on the economic growth makes both economic developmental approaches distinct. It can be also concluded that the urbanization as a phenomenon requires multi-dimensional and multi-disciplinary view to improve and understand urbanization trends.

Keywords: Urbanization, China, Pakistan, Migration, Industrialization, Natural processes, Socio-economic growth

\section{Introduction}

Urbanization refers to the growth of people who live in cities and mainly leads physical expansion of city areas, or demographic move from rural to urban areas as well as urban land growth that's been observed worldwide in the recent number of decades. According to academic literature, urban population has been increased 169\% from 1970 to 2011 (1.35 billion to 3.63 billion) globally (United Nations, 2011). Urbanization has taken palace more noticeably in under developed and developing countries than developed countries (Angel, Parent, Civco, Blei, \& Potere, 2010), and it will continue to grow specially in emerging economies and predicted to be expend at exponential rate. Growing trend of urban population globally is creating socio-economic problems for developing countries like delivery of services to public, congestion, housing, education, health and unemployment (Bloom, Canning, \& Fink, 2008).

Enormous studies have been conducted and focused on urbanization, demographic urbanization, urban land expansion and used the terminology like city proper urbanization, agglomeration and metropolitan areas to define and discuss urban trend. However, the critical factors that lead urbanization or urban expansion is relatively less understood and comparative studies on main factors of urbanization among different countries are rarely observed. Interestingly, characterizing driving forces of urbanization is the prerequisite to not only understand the urbanization process itself, and ecological consequences but also support fit for possible urban planning and management strategies (J. Wu \& Hobbs, 2002; W. Wu, Zhao, Zhu, \& Jiang, 2015).

China and Pakistan in Asia continent are also urbanizing with fastest pace in Asia as both are having strategic drifts and economic growth. It is necessary to determine what major factors are leading rapid urbanization in both countries as China that is the world's most populous country and Pakistan that is experiencing quick growth in population and man power. Several studies are carried out on urban expansion in China specially focusing on urban expansion in the Yangtze River Delta and the Pearl River Delta (Gu, Wu, \& Cook, 2012; Tan, Tan, Li, Xie, $\& \mathrm{Lu}, 2005)$ but not on major factors leading swift urbanization in China. Similarly, some urban studies are brought together on Pakistan i.e. industrial, agricultural growth and urbanization (Muhammad \& Ishfaq, 2011), Urbanization and Governance Perspective (Nasira Jabeen, Umm-e- Farwa, 2015) whereas it is hard to find data on main reasons of urbanization comparatively. 
In this paper we have quantified and compared major factors that lead rapid urbanization in two developing countries Pakistan and China which are urbanizing very fast, and how urbanization is taking place in both countries. The objectives of this study were to (1) quantify main factors that cause drastic urbanization in China and Pakistan and (2) to compare general trends of urbanization, particularly urban growth pattern in both countries in the context of socio-economic, natural processes, industrialization and government policies.

\section{Urbanization - Literature}

It's been observed that natural processes and socio-economic problems have contributed to urbanization up to great extent (Xiao, Shen, Ge, Tateishi, \& Tang, 2006), like income of individual, education, health, basic facilities. On the other hand, natural processes include natural increase in population, natural disasters like floods, environmental changes, droughts, and earthquakes. Moreover, the industrialization and government policies also affect the economic development and urbanization (Evans, 2015; Hu, 2013). Natural increase in population is one of the reason that derived urbanization (Angel, Parent, Civco, Blei, \& Potere, 2011). The difference in birth- and death rate is much in different areas and that caused urbanization, as life expectancy is greater and in some regions and that lead to natural increase in population, (Angel et al., 2010; Martine \& Alex Marshall, 2007). Furthermore, floods (He, Tian, Shi, \& Hu, 2011), affects people economically a lot and one of the reason of rural-urban migration is flood. The reason behind it is climate changes which have also affected the life of people specially who live near coastal areas. People and economic activities are always attracted by coastal zones because of their natural resources and trading opportunities.

Interestingly, the number of the world's biggest urban communities are on seacoasts and near to the mouths of the great rivers (Raleigh, Jordan, \& Salehyan, 2008). People who live close to coastal areas are often affected by floods. Flood incidents have affected the biggest numbers of people, between 2000 and 2008 averaging 99 million people per year (Johnson, 2010), as result people dispose of their liquid assets for survival during floods, and when they are finished with assets, they choose to migrate (Rayhan \& Grote, 2007).

Therefore, people leave their hometowns and move towards metropolis for better livelihood and incomes. Beside these other natural disasters have turned out to be more regular and more serious during the last two decades, distressing a number of cities. According to The United Nations Environment Programme (UNEP), from 1980 to 2000, 75\% of the world's total population lived in areas affected by a natural disaster (United Nations Environment Programme [UNEP], 2005). Due to environmental changes and unfavorable weather conditions such as, heavy rains, extreme cold and intense summer people shift to other areas. Most of the migration trend movement of people is currently from informal settlements where housing conditions are generally very poor and even the simplest protective infrastructure is missing. In the recent years, the fluctuation in climate conditions are more rapidly i.e. in some parts of the region, the key influence on urbanization is the movement of people evacuated by drought and famine (Rayhan \& Grote, 2007).

The reasons behind that widespread scarcity of food have several factors including crop 
failure, and less strategic government policies. Beside these factors earthquakes as well have contributed to urbanization (Bloom et al., 2008; Shen, Cheng, \& James, 2005), as location and topography of different regions make it vulnerable to earthquakes and landslides. An earthquake can bring homes, hospitals, and schools falling down with terribly disastrous consequences. In 2009, millions were affected by the earthquake all around the world (Johnson, 2010). After facing such problem and risks of location, gravity and frequency of environmental people choose to migrate from such affected villages and small towns and move towards urban areas, as cities look safer and have greater access to variety of facilities.

These natural processes push people to move from rural areas to semi urban areas and semi urban areas to cities. Natural processes including natural disasters affect people a lot, and these risks that could have serious social and economic impacts on an individual or family's social standing and economic status. According to United nations, urbanization is linked with economic and societal revolution (United Nations, 2014). The relationship between poverty and urbanization is strong as numerous low income groups live in high danger places and have poor quality shelter, as well as they have fewer defensive infrastructure and less resources to call on after being encountered by disasters (Johnson, 2010). As they face harsh life in such area and experience socio-economic issues i.e. poverty, unemployment, lack of public services and as a result people choose to migrate (Kugelman, 2013). And migration contribute on average between 40 to $50 \%$ of overall urban population growth (Bloom et al., 2008; Chen, An, Yu, \& Chen, 2007).

For some, migration from deprived areas to cities brings real improvement because skillful workers get paid higher wages in the urban areas and this maintains broader development and encourages education. This is because urbanization is connected to economic development. It is one of the reasons that the people move from rural areas to cities and towns for better life, unproblematic reach to variety of facilities and livelihood. It's also one of the reason, the cities are constantly creating a center of attention for new migrants (Nasira Jabeen, \& Umm-e- Farwa, 2016).

Government policies also influence urbanization as government provide favorable environment and infrastructure to different industries and increase industrialization in particular regions, so that later new cities and towns can be built and rural population can be facilitated in such industrial and economic zones not only with basic facilities but also with good employment opportunities and facilitating opportunities (Weziak-Bialowolska, 2016). These pulling factors attract and compel different segments of people to look towards metropolitan cities for better education, employment opportunities and greater access to different services. Moreover, cities not only provide basic facilities like, health, education and transportation but also provide comparative cheap transportation cost and easy access to variety of things and places. As a result, these major factors drive rapid urbanization not only in poor countries but also in developing and developed countries.

\section{Data Sources and Methods}

The methodological aspect used to define the research design and approach to target the research questions (Saunders, Lewis, \& Thornhill, 2009). Philosophically, the interpretive 
approach is followed as the research is addressing social aspect of the society and social change. In the deductive manner, the cross-sectional study is recorded in the case of socio-economic, industrial growth and government policies as its only dealing with year 2014 and 2015. However, the longitudinal trend can be observed while analyzing "natural processes' specifically the trend between year 2001 to 2016 is recorded.

Data sources for analysis: To achieve the prime goal to compare the urbanization trend between China and Pakistan, the secondary data sources used to understand the trends. For example: to define on the basis of the effect of 'natural processes' the data source from 'Centre for research on the epidemiology of disasters (CRED) and World bank reports are being used during the study. Comparatively, the other sources are also being referred to review the findings i.e. United Nations office for disaster Risk Reduction (UNISDR). For comparing the socio-economic factor-based analysis, this research majorly dependent on the data sources provided by the 'National bureau of Statistics of China', 'Pakistan bureau of Statistics', and 'World Bank' as they can be considered as reliable data source for longitudinal and cross-sectional studies in the field of social sciences. During the analysis of industrial and government policies, heterogeneity in the data sources can be observed, as the statistics from the 'Ministry of Foreign Trade and Economic Co-Operation'(MOFCOM), 'State Bank of Pakistan' (SBP), 'United Nations Development Programme' (UNDP), and 'World Bank', as the heterogeneity increase the data reliability and confidence in the findings.

To increase the validity of the scale in the current descriptive study, the items to measure each variable of urbanization will be highlighted here. Specifically, to gauge the natural processes, items like Natural increase in population (Awumbila, 2014; Barnett \& Adger, 2007; Martine \& Alex Marshall, 2007; Wenze Yue, Yong Liu, 2013), Earthquakes (Asian Development Bank, 2006; Nasira Jabeen, Umm-e- Farwa, 2015), and Floods (Awumbila, 2014; Barnett \& Adger, 2007; Martine \& Alex Marshall, 2007; Nasira Jabeen, Umm-e- Farwa, 2015) etc are already been observed in the previous studies. To scale the influencing factors i.e. Basic Facilities and Employment (Barnett \& Adger, 2007; Martine \& Alex Marshall, 2007; Murtaza Haider, 2010; Nasira Jabeen, Umm-e- Farwa, 2015; Wenze Yue, Yong Liu, 2013), have been recorded in the previous studies to weight 'socio-economic factors. The factors like regional industrial growth (Barnett \& Adger, 2007; Evans, 2015; Long, Li, Liu, Woods, \& Zou, 2012; Wenze Yue, Yong Liu, 2013) and government policies (Evans, 2015; S. Liu, Li, \& Zhang, 2003; Shin, 2015; Wenze Yue, Yong Liu, 2013) to raise urbanization have been recorded to measure industrialization and government policies trend. The purpose to mention the previous trend is to highlight the significance of the items and factors used to define each of the discussed three variables in the current study.

\section{Analysis and Findings}

The current paper will make an overview of the urbanization trend in the comparatively manner and analyze situation in China and Pakistan on the basis of 'migration and natural processes', infrastructure and 'socio-economic facilities' and 'industrial and governing policies'. 


\subsection{Migration and Natural Processes}

According to International federation of Red Cross and Red Crescent Societies Urbanization and growth of cities are caused by several different factors including internal and external migration that take place due to natural disasters (IFRC, 2010). Natural disasters affect people economically a lot and they choose migrate to develop areas (Raleigh et al., 2008), and it is one of the reason of internal migration where affected people move from rural to urban regions because of attractive social and economic opportunities, better living standards with improved wages and other facilities of life (S. Liu et al., 2003). On the other hand, the main factors that cause external or international migration include political, religious or economic oppression, and military pressure and war that create refugees as well (Jacobson, 1976).

At present, approximately half of the world's migrant are economically active worldwide. Migration external as well internal have proven an important determinant of rapid urban growth (Shin, 2015). Therefore, the expansion of the already urbanized areas can be caused by the arrival of new migrants from neighboring countries usually skipped from wars, and affected by natural disasters with in the country. Accordingly, significant migration, together with high rate of overall population increase have caused unplanned rapid growth in low income regions near many large cities without any parallel development of public services and facilities (Cohen, 2006).

\subsubsection{Migration and Natural Processes in China}

Much of the China's urbanization has been caused by migration in last three decades particularly internal migration. Before the late 1970s, urbanization process in China was not primarily different from other developing countries like Pakistan. The rural to urban migration was severely prohibited through the stringent household registration that is (Hukou) system, even that here rural-urban migration helped existing large as well medium-sized cites to grow and that created urbanization process in that time (Zhu \& Chen, 2010).

Later open-door policies introduced in China in the late 1970s and that completely changed the situation and increased urbanization only due to policies but also rural to urban migration (Zhu, 2015). On the other hand, due to natural disasters millions of people are affected every year in China including earthquakes, floods, storms, and extreme temperature in winters. As presented in Table 1 China has faced 73 floods in last six years and only floods have affected 300 million residents in China. Similarly, Earthquakes 40 and storms 78 times are come across respectively, that also have affected millions of citizens in main land China. These incidents eventually lead to migration to big cities as theirs home, crops and business are blown by disasters and they move for survival to cities. This phenomenon has also contributed to urbanization and has widened already established cities.

Urbanization is increasing in China that is not only providing many opportunities, but also challenges with important policy implications and those challenges deserve vigilant assessment for better understanding of China's urban progression and related policy making (Zhou, Zhang, \& Shen, 2015). 
Although now a day's Chinese government is making policies to make new cities and towns, so that rural population can be facilitated in these new urban regions, but it's not only reason behind rapid urbanization and rural urban migration in china (Zhu, 2015). The interrelated factors, namely socio-economic and natural process are driving forces, and enhancing factors. Highly populated areas with improved transportation and communication condition and basic facilities like, education, employment, health facilities and so on make difference in rural urban areas that induce rural residents migrate to urban areas (Zhu \& Chen, 2010).

Table 1. Summary of natural disasters in last 6 years

\begin{tabular}{|c|c|c|c|c|c|c|c|c|}
\hline \multirow[t]{2}{*}{$\begin{array}{l}\text { Nature } \\
\text { incident }\end{array}$} & \multicolumn{2}{|c|}{$\begin{array}{l}\text { Number } \\
\text { incidents }\end{array}$} & \multicolumn{2}{|c|}{ Total deaths } & \multicolumn{2}{|c|}{$\begin{array}{l}\text { Total affected } \\
\text { ( in millions) }\end{array}$} & \multicolumn{2}{|c|}{$\begin{array}{l}\text { Damage USD } \\
\text { (in millions) }\end{array}$} \\
\hline & China & Pak. & China & Pakistan & China & Pakistan & China & Pakistan \\
\hline Earthquakes & 40 & 7 & 4163 & 753 & 75.656 & 0.704 & 16.130 & 0.100 \\
\hline Floods & 73 & 24 & 5297 & 4319 & 87.731 & 36.427 & 87.731 & 18.001 \\
\hline Storms & 78 & 3 & 1316 & 51 & 41.692 & 0.004 & 41.692 & 0.080 \\
\hline Landslides & & 4 & & 203 & & 0.030 & & 0.018 \\
\hline $\begin{array}{l}\text { Extreme } \\
\text { temperature }\end{array}$ & 2 & 4 & 47 & 1368 & 1.901 & 0.080 & 1.901 & 0.018 \\
\hline
\end{tabular}

Source: (The EM-DAT, 2017) Note: Storms include Cyclones \& convective / Pak.=Pakistan.

\subsubsection{Migration and Natural Processes in Pakistan}

Internal and external migration has caused rapid urbanization in Pakistan. Due to natural disasters many Pakistanis are leaving their home towns to seek jobs in cities include farmers and fishermen, because their sources of revenue have been devastated by water shortages and droughts and other disasters in many regions of Pakistan (Nadeem, 2015). Furthermore, due to frequent floods, earthquake, Cyclones, Land sliding in rural areas of Pakistan many families have lost their homes and have been shifted to big cities (Hasan, 2016), such as Karachi, Lahore, Faisalabad and Hyderabad, and remaining rural residents in Pakistan are moving to cities because of extreme temperature in some areas see (Table 1). Mostly people believe that in urbanized areas access to different facilities is easily as compare to their areas such as better education, healthcare, employment and other basic services (Kugelman, 2013). Since year 2010 Pakistan's rank is among top 10 countries that have been most affected storms, floods, heat waves etc and that have affected a lot Pakistan physically and financially. Detailed categories of the different nature disasters are presented in (Table 1).

Internal migration is not new problem in Pakistan but much of the external movement also has been driven by war and conflict in Pakistan. In 1947 at the time of Indo-Pak partition, in millions Indian Muslims came into Pakistan, majority of them established their roots in urban regions of Punjab and Sindh provinces. In 1965 and 1971 during war with India again more Indian Muslims streamed into different cities of Pakistan. During anti-Soviet insurgency in 
the 1990s, nearly 4 million Afghan refugees came into Western Pakistan; later in 1992, they fled camps and started businesses in Quetta and Peshawar (Nasira Jabeen, Umm-e- Farwa, 2016).

Nowadays, urbanization in Pakistan continues to be stimulated by war, insecurity, as well as economic needs. Due to Pakistan military operations in the rural north-west have compelled people flee to different cities. As Table 2 shows net migration rate in Pakistan is 1.69 that reflects migrants are coming more inside Pakistan and refugee population in Pakistan that is more than two million. On the other hand, social progress index is low and terrorism index is high for Pakistan. More details on net migration, refugees and terrorism index are presented in Table 2.

Table 2. Migration refugees and terrorism

\begin{tabular}{lll}
\hline A Quick Snapshot & China & Pakistan \\
\hline Net Migration rate (per 10,000) (2014) & -0.33 & -1.69 \\
Refugee population by country or territory of origin in (millions) & 0.298 & 2.614 \\
Terrorism index (2014) & 6.29 & 9.07 \\
Social progress index (2014) & 92 & 122 \\
\hline
\end{tabular}

Sources: (Admin, 2014; Miguel Barrientos, 2015; Porter, Stern, \& Artavia Loría, 2015; World Bank, 2016).

\subsubsection{Challenges in Both Countries}

These socio-economic factors with government policies boast urbanization in developing countries like Pakistan and China. But these factors especially migration problems deserve attentive assessment for better understanding of issues related to security as well as law and order situation. The observed high migration rate is producing low social progress and these migration patterns are challenge for Pakistan. On the other hand, intra country migration is emerging problems of polarized facilities in China that could increase inequality as well. The variety of reports have showed that labor markets in developing countries are hollowing out and polarizing (The World Bank, 2016). The share of employment in high skilled jobs, high-paying and low skilled jobs, low-paying is growing. In contrast, the share of employment in middle-skilled jobs such as clerks and machine operators middle-paying is being compressed (Klein \& Sauer, 2008).

\subsection{Socio-Economic Facilities and Urbanization}

In developing countries most of the people live in rural areas as they often don't participate in tax process so government decide they are not entitled to public services or security. As a result, they find themselves ignored and deprived of basic services therefore they try to move to urban areas. As government fails to provide basic social services, such as clean water, sanitation, health and education facilities compel rural residents to look for better life in cities that cause rapid urbanization (IFRC, 2010). Furthermore, urban regions have various 
characteristic of metropolitan life with quality and facilities including availability of communication socio-economic facilities such as, economic development, labor markets, quality of institutions and safety (Xibo \& Zaigao, 2011), and that attract investment and financier to develop huge urban projects, which are supposed to become smart residential places in future, and that create a center of attention not only for creative individuals (Weziak-Bialowolska, 2016) but also different segment of society to become new residents in such cities. These features of cities with socio-economic facilities and quality of life pull people towards urban areas (Thrift, 2012).

\subsubsection{Access to Basic Facilities in China}

As compare to Pakistan, in China basic facilities are much better not only in cities but also in rural areas. Basic health care, education, transportation, cheap energy, water supply and sanitation are already provided in big cities along with third and fourth-tier cities, but there is still difference in living standard in rural and urban areas (Table 3). Chinese government is making policies to create more cities and move rural population to new cities in order to increase their living standard and income, so that further productivity gains can be achieved by moving workers from less to more productive sectors.

In early 2014, a new urbanization plan was released to focus on human-centered and environment friendly urbanization. Government is trying to providing cheap energy to public policies have increased in education attainment and living standards, recent fiscal measures indicate, to support growth and speed up infrastructure with social housing investment (Surveys, 2015). In China generally people move to urban areas because of low income and easy access to transportation, as mostly migrants belong to agricultural sector and their average disposable income per capita is about 1/3 of that in urban areas (Evans, 2015). Eventually, low income, market reforms, industrialization, Hukou restructuring and government push and pull policies have stimulated urbanization in China.

Table 3. Access to basic facilities

\begin{tabular}{lll}
\hline A Quick Snapshot & China & Pakistan \\
\hline Health expenditure, total (\% of GDP) & 5.548 & 2.613 \\
Health expenditure per capita, PPP (2014) (millions) & 730.517 & 128.988 \\
Health expenditure, public (\% of GDP) (2014) & 3.095 & 0.919 \\
Improved water source (\% of population with access) & 95.5 & 91.4 \\
Improved sanitation facilities (\% of population with access) & 76.5 & 63.5 \\
$\begin{array}{l}\text { Improved sanitation facilities, urban (\% of urban population with } \\
\text { access) }\end{array}$ & 86.6 & 83.1 \\
$\begin{array}{l}\text { Improved sanitation facilities, rural (\% of rural population with } \\
\text { access) }\end{array}$ & 63.7 & 51.1 \\
Improved water source, rural (\% of rural population with access) & 93 & 89.9 \\
\hline
\end{tabular}




\begin{tabular}{lll}
\hline $\begin{array}{l}\text { Improved water source, urban (\% of urban population with } \\
\text { access) }\end{array}$ & 97.5 & 93.9 \\
\hline Access to electricity (\% of population) (2014) & 100 & 97.534 \\
Access to electricity, rural (\% of rural population) & 100 & 95.625 \\
Access to electricity, urban (\% of urban population) & 100 & 100 \\
Rail lines (total route-km) & 67212 & 9255 \\
Railways, goods transported (million ton-km) & 1980061 & 3301 \\
Railways, passengers carried (million passenger-km) & 723006 & 20288 \\
Fixed telephone subscriptions (millions) & 230.996 & 3.538 \\
Fixed broadband subscriptions & 277.046 & 1.793 \\
Mobile cellular subscriptions (millions) & 1291.984 & 125.899 \\
\hline
\end{tabular}

Snapshot 2015 / Source: (World Bank, 2016).

\subsubsection{Access to Basic Facilities in Pakistan}

In Pakistan access to basic facilities is not as good as should be, and most of the basic facilities are in main cities, whereas most of the rural areas are deprived of basic facilities. According to the Pakistan Social and Living Standards Measurement Survey (PSLM) 2014-15 for the year, $43 \%$ of the household are not satisfied from basic health facilities and $52 \%$ from the services of law enforcement agencies, whereas majority of the rural and urban population is not satisfied with economic situation of the community, and still in greater part of the population is deprived of clean water as more than $40 \%$ of population drink through less clean channel and dug well water (PBS, 2016).

The quality parameters for sanitation facilities is even more compromised than the available water supply in Pakistan, as more than the half of population does not have sufficient access facilitating environment. Statically every year hug budget used to be allocated for health (Table 3), but only small portion of the allocated budget in used in the effective manner (SPDC, 2001). Similarly, the access to electricity is justified statically, as shown in the table 3. However most of the rural areas face 6-8 hours' load shading every day. Except these facilitating facilities government is also struggling to provide usually basic facilities like transport, housing, education and employment to urban residents (Nasira Jabeen, Umm-eFarwa, 2015).

Further a snapshot of facilitating facilities is stated in (Table 3). These infrastructure deficits with related urban decline are only a demonstration of much more difficult structural dynamics but also demonstration of restrictions. The lack of employment augmentation for the youth (Thrift, 2012), low rate of entrepreneurship because of poor economic growth (Hull, 2009), insufficient mechanism of local government and inadequate security (Barnett \& Adger, 2007), force rural residents to move towards comparatively better cities for attainment of 
basic facilities and life style.

\subsubsection{Infrastructure Development Pace in Both Countries}

Access to basic facilities and infrastructure development pace reflect seriousness and demonstration of government policies towards these emerging trends. But in Pakistan basic facilities and infrastructure development pace is very slow due to corruption of political leaders from top to bottom, although in every budget a huge amount is allocated for infrastructure and developmental schemes. Beside this no seriousness of local government towards development and infrastructure gap has declined competitiveness of Pakistan. Furthermore, in future urban infrastructure that is already experiencing stress will be short of to provide basic amenities, and rising cities will encounter Greenfield development problems (Naphade, Banavar, Harrison, Paraszczak, \& Morris, 2011).

On the other hand, Chinese government is substituting small rural homes with tall buildings, providing roads and enhancing urban infrastructure and significantly changing the lives of rural residents. Huge portion of sub-national debt is used for urbanization and infrastructure projects and that is one of the major drivers of urbanization and growth. According to Chinese government modernization plan $60 \%$ by 2020 (Hu, 2013), and 70\% of the country's population, around 900 million residents, will be living in cities by 2025 (Evans, 2015).

About the infrastructural comparison between china and Pakistan, it can be observed that the health expenditure in Pakistan is comparatively half of the China's spending of the total GDP in percentage. This is the reason that the health expenditure per capita in Pakistan is almost 3 folds less as compare to the China's expenditure as shown in the table. While analyzing the percentage of population having the access to the clean water and sanitation facilities in Pakistan are comparatively low. However, the water and sanitation facilities in the urban region of Pakistan and China are almost same in percentage. Interestingly, in the urban region of both countries, the balanced and uninterrupted electric supply is recorded statistically. However, because of the energy crisis in Pakistan, the interruption in the electric supply is the emerging challenge for providing basic facilities in the urban areas of Pakistan.

\subsection{Industrialization and Government Policies}

Industrial development plays an important role in the economic growth of countries and enhances urbanization (S. Liu et al., 2003), as industrialization and government policies are closely related to urbanization as observed in the literature. Government policies that encourage industrialization in rural areas lead to regional development (Wei, 2007), since industries need land, energy, communication and infrastructure which swiftly alter the agricultural land into suburbs and later into cities plus change physical and human landscapes (Antrop, 2004). These industrial regions and zones initiate a development process that create substantial rate of rural housing and infrastructural development including employment, increase in living standard, and basic facilities and so on in rural areas and in its soundings (Xiao et al., 2006). 


\subsubsection{Industrial Regional Growth in Government Policies in China}

Before the year 1978, China had traditional central planned economy however after the year 1978, Chinese government launched economic reforms that changed the traditional central planning economy into a market based economy (Kniivilä, 2007; Xiao et al., 2006). With the passage of time these reforms have contributed significantly to the increase in rural income levels and employment in China (Wei, 2007), and the primarily agricultural economy has been transformed into an urban industrial economy. The growing industrial regions have shaped a magnetic force that induce temporary migrants, and rural migration of China is linked to rural development by remittances, physical and human capital carried back via returning migrants (Ma, 1999).

The rural areas of China have experienced an unprecedented development particularly the eastern coastal China has experienced rapid urbanization due to industrialization. Moreover, the urban population of china is $28.8 \%$ of total population as mentioned in the table 4 . Chinese government policies like, using the sea to connect China with the global economy has also developed rapidly the eastern coastal side of China, because economic reform and open-door policy augmented regional industry, that played a major role in promoting China's rapid economic growth, and changed not only urban but also rural areas along with socio-economic development (Long, Zou, \& Liu, 2009).

Urban population of China is growing 3.3 annually and that is significant increase in urban population as mentioned in table 4. Beijing-Tianjin-Hebei, Yangtze River Delta and Pearl River Delta have grown quickly due to industrialization, and it has also increased the economy of the regions during the last three decades with fast urbanization and integrated development in the regions (Y. Liu, Wang, \& Long, 2008). Chinese government policies have not only raised urbanization and lessen rural areas but also increased the living standard of people and economic growth with 6.9 annual growth of GDP. Furthermore, the government policies have also demonstrated to be evident of urbanization as government makes policies to develop rural regions, makes new towns so that living standard of people can be raised there (Evans, 2015; Hu, 2013; Surveys, 2015). The industrialization has raised living standard of people, supplied basic facilities, employment and other socio-economic amenities in newly established industrial zones (Long et al., 2012).

Table 4. An Overview of Urbanization and economic factors in perspective of Industrialization and government policies

\begin{tabular}{lll}
\hline A Snapshot 2014-15 & China & Pakistan \\
\hline Population, total (millions) & 1371.220 & 188.925 \\
Birth rate, crude (per 1,000 people) & 28.845 & 12.1 \\
Death rate, crude (per 1,000 people) & 7.3 & 7.1 \\
Life expectancy & 75.7 & 66.2 \\
Urban population (millions) & 762.590 & 73.224 \\
\hline
\end{tabular}


Urban population (\% of total population)

Urban population growth (annual \%)

55.6

3.3

45.5

25.2

Population living in slums (\% of urban population) 12014)

Rural population (millions)

Rural population (\% of total population)

Rural population growth (annual \%)

Population in largest city (millions)

Land area (sq. km) (2015)

Urban land area (sq. km) (2010)

Rural land area (sq. km) (2010)

Population density (people per sq. $\mathrm{km}$ of land area)

Labor force, total (millions)

Industry, value added (annual \% growth)

GDP (in Billion) (2014)

GDP growth (annual \%)

FDI (in millions) (2014)

Human Development index (2014)

Forest area (sq. km)

Forest area (\% of land area)

Agricultural land (sq. km)

Agricultural land (\% of land area) (2014)
608.630

115.701

44.4

61.2

$-2.2$

1.3

23.741

16.618

9388211

770880

380679.3

35871.9

8868577.0

751709.5

146.1

245.1

804.772

66.190

6.2

4.8

10351.1

243.6

6.918

4.712

121500

2847

0.727

0.538

2083213.0

14720.0

22.2

1.9

5145530.0

362520.0

54.8

47.0

Snapshot 2015 Sources: (mofcom China, 2017; SBP, 2017; UNDP, 2017; World Bank, 2016).

\subsubsection{Industrial Regional Growth in Government Policies in Pakistan}

Industrial development and agriculture growth are main reasons of economic development in most of the countries. In the case of Pakistan, it is generally known as an agrarian country and most of the area is covered by agriculture. Government of Pakistan has always been focused on economic policies so that higher growth rates can be achieved and policies to improve the rate of growth by using contemporary technologies (Dawn, 2012; Muhammad \& Ishfaq, 2011). By the time industrial share of Pakistan in economy has been increased greatly and its economic structure has changed since its dependence in 1947, and now days the share of industries and services has improved and the ratio of industrial growth and agriculture that Pakistan is transitioning towards industrial economy (Muhammad \& Ishfaq, 2011).

As compare to industrialization in China and government policies, government of Pakistan 
has been making policies for economic growth, generating revenues, increasing exports and lessening imports (Avrupa Komisyonu, 2006), but has not get paid attention towards regional growth is rarely observed. The unplanned urbanization and unplanned infrastructure for regional population and equality is creating big obstacles for urban growth. Because of the Pakistan's low score in Human Development index (DHI) as compare to China (Table 4). Although policies have increased industrial growth and laid economic development but on other hand have pushed the urbanization rate in regions and cities with industries like, Karachi, Faisalabad, Lahore, Sialkot and Hyderabad (Kedir, Schmidt, \& Waqas, 2016). Alone Karachi has attracted millions of people due to its big markets, industries and employment opportunities including other amenities. The mega cities in Pakistan are attracting human resources from different regions of the country for better employment, basic facilities and living conditions which are leading urbanization. Industrialization and regional industries not only are pushing traditional cities to urbanize but also nearby other small cities and introducing the concept of satellite town in the developing countries.

In terms of population comparison, it can be observed in the first overview that the China's population is 7 times high as compare to Pakistan's population analysis. Moreover, the birth rate is twice as compare to Pakistan. However, the death rate is almost comparably same. The healthy life expectancy in China is high because of multiple supportive factors i.e. food resources and medical facilities. In the urbanization related factual analysis, Pakistan's urban population is 10 times lower as compare to China's urban population segment. Interestingly, the increasing rate in China is higher as macro and micro level forces are more appreciating the citizens to get migrated to urban regions in China, and the 10 times more available urban space in China letting the policy makers to initiate real-estate strengthening strategies to involve private investments in the urbanization process.

It has also been recorded that the strong GDP and its growth is encouraging the decision makers to develop mutual shared value and benefits for citizens by introducing new policies for urbanization in China. Moreover, the agricultural land in Pakistan is also making challenges for urban development and pulling citizens to experience urban development and facilities in the case of Pakistan.

\subsubsection{Industrial Growth and Government Policies in Both Countries}

It is being observed that the economic reforms in 1978 has led industrial growth in China and that eventually caused urbanization specially in Beijing-Tianjin-Hebei, Yangtze River Delta and Pearl River Delta regions (Y. Liu et al., 2008). Furthermore, these reforms led economic growth and development in these regions and pioneered urbanization and future urban trends in China e.g. industry and urbanization relationship. Moreover, government of China is also making policies to move rural residents to urban areas or newly built cities and economic zones to elevate their living standard and provide them amenities of life (Hu, 2013; Surveys, 2015).

This shows the government willingness and policies that lead urbanization. In comparison to China, in Pakistan wherever industry has grown urbanization has also taken place but government's involvement has not been observed and the policies that encourage 
industrialization in different regions or the policies that shift people from backward areas to comparatively better areas as government of China as done. Because Government of Pakistan has given priority to higher growth rates of agriculture sector (Dawn, 2012; Muhammad \& Ishfaq, 2011) and economic growth (Avrupa Komisyonu, 2006).

\section{Discussion}

Urbanization is most intensive research topic these days. Many studies have been conducted on different problems and causes associated with urbanization in different real life situations. Some authors have mentioned only some causes of urbanization and others have focused on other topics like floating population, migration, and land expansion (He et al., 2011; S. Liu et al., 2003; Ma, 1999). The research findings presented in this paper contribute to filling the above knowledge gap in comparative manner from the perspective of major factors that lead rapid urbanization in Pakistan and China.

This study provides set of factors that mostly influence urbanization not in only developing countries but also in developed countries. It's essential to identify major factors which can be classified as main reasons behind urbanization. It will help to understand environment clearly and to suggest and propos appropriate policies to cope with future challenges that emerge due to urbanization. Our study has covered different issues that lead urbanization and has categorized them into three main factors namely Socio-economic issues, Natural processes and Industrialization and government policies.

\subsection{Natural Processes}

We found that $t$ natural processes affect people a lot, and have serious social and economic impacts on an individual or family's social standing along with economic status. These are also pushing sub-factors; since these induce people move from under developed to developed or unfavorable to favorable areas. Natural processes like natural disasters such as floods, environmental changes, droughts, earthquakes and natural increase in population etc are also found as factors that lead urbanization. It is comprehended that natural processes have impacted more on Pakistan's urbanization than China. In recent years the continuous natural disasters have derived much urbanization in Pakistan as people are moved to big cities after hit by consecutive floods and heavy rains in different areas of country.

Beside these earth quacks, droughts and famines, widespread scarcity of food, including crop failure compel people to migrate (United Nations Environment Programme [UNEP], 2005) and this has been found in different provinces of Pakistan and China. Intense summer in different cities of Pakistan due to climate change also have impelled people to move coastal cities like Karachi or cities that are comparatively with less temperature. Furthermore, according to (Cohen, 2006) natural increase in population is also a source of urbanization in Pakistan, due to not having proper family planning policies and less in China. The difference between birth and death rate is vast in some areas and that has also caused urbanization in cities with the passage of time. Therefore, these natural processes coerce people leave their hometowns and move towards metropolis for better livelihood and incomes. 


\subsection{Socio-Economic Issues}

Findings show that every person looks for social and economic benefits like good income, better education either for him or his family, easy and fine access to health, security and favorable environment and other basic facilities. These socio-economic issues are also called pushing factor because mostly lead internal and external migration. When a person does not have sufficient access to these socio-economic facilities he tries to migrate to areas that provide such benefits. Some migrate to get good wages in developed areas and try to improve living standard and those who have good income move to urban areas for better education, health facilities, better communication facilities and life style. This mostly encompasses internal migration.

We have noticed this trend more in China where mostly people move to big cities for better income particularly (Chan, 2010), whereas as in Pakistan people migrate due to multiple above mentioned reasons, i.e. due to war and conflicts (Kugelman, 2013), less security (Gabriel Domínguez, 2014), and political pressure (Haider et al., 2014). Here external or international migration also takes place as military operations in Pakistan and Afghanistan are taking place against terrorist, and millions of refugees have crossed border of Pakistan and living in big cities of Pakistan that has also caused security threat for Pakistan as well (Nasira Jabeen, Umm-e- Farwa, 2015).

\subsection{Industrialization and Government Policies}

In the current study industrialization and government policies are proved to be pulling factors of urbanization, as it increases the labor, HDI and inversely affect agricultural sector. We observed that the industrialization has taken place in China and Pakistan have pulled the rapid regional development along with economic growth and that has led urbanization. In China namely, Beijing-Tianjin-Hebei, Yangtze River Delta and Pearl River Delta are grown quickly due to industrialization and in Pakistan Karachi, Faisalabad, Lahore, Sialkot and Hyderabad. Industrialization requires land, energy, communication and huge infrastructure in the place where exists, and according to (Antrop, 2004) this rapidly changes the agricultural land into industrial hubs. These industrial hubs create extensive rural housing, infrastructure, employment and new markets (China Briefing, 2011; Vidová, 2010).

Furthermore, later government provides basic facilities in such areas like health centers, schools, public transportation, and eventually these become urban centers that attract other rural areas and in its soundings (China Briefing, 2011; UNIDO, 2015). However, the government policies are also proving to be evident of urbanization since government makes policies to develop rural regions, makes new towns so that living standard of people can be raised there (China Briefing, 2011; UNIDO, 2015; Vidová, 2010). This trend has been noticed more in China as compare to Pakistan. The Chinese government has initiated modernization plan and according to $60 \%$ by 2020 (Hu, 2013; Surveys, 2015), and 70\% population China, around about 900 million citizens will be living in cities by 2025 (Evans, 2015).

\section{Conclusion}

Two countries like China and Pakistan are developing countries which are also urbanizing at 
fastest pace in Asia. It is anticipated both countries will grow on average twice as fast as urban population. Rapid urbanization in cities due to globalization is creating problems for developing countries like delivery of services to public, congestion, housing, education, health and unemployment etc, and that is creating challenges for governments. The driving forces of rapid urbanization have been identified in this paper for China and Pakistan. Multiple factors affect lead rapid urbanization in both countries and that can be summed up in socio-economic, natural processes, industrialization and government policies including their sub factors. Government must consider these factors while making policies, since it's very important to understand the urbanization process itself, its outcomes, ecological consequences and socio-economic issues for best possible urban planning and management strategies.

\section{References}

Admin, I. (2014). Global Terrorism Index Report 2014. Retrieved April 24, 2017, from http://economicsandpeace.org/report/the-economic-cost-of-violence-containment/global-terro rism-index-report-2014/

Angel, S., Parent, J., Civco, D., Blei, A., \& Potere, D. (2010). A Planet of Cities: Urban Land Cover Estimates and Projections for All Countries, 2000-2050, 103.

Angel, S., Parent, J., Civco, D. L., Blei, A., \& Potere, D. (2011). The dimensions of global urban expansion: Estimates and projections for all countries, 2000-2050. Progress in Planning, 75(2), 53-107. http://doi.org/10.1016/j.progress.2011.04.001

Antrop, M. (2004). Landscape change and the urbanization process in Europe. Landscape and Urban Planning, 67(1-4), 9-26. http://doi.org/10.1016/S0169-2046(03)00026-4

Asian Development Bank. (2006). Urbanization and Sustainability in Asia.

Avrupa, K. (2006). Pakistan-European Community Country Strategy Paper for 2007-2013. Retrieved from http://eeas.europa.eu/pakistan/csp/07_13_en.pdf

Awumbila, M. (2014). Linkages between Urbanization, Rural-Urban Migration and Poverty Outcomes in Africa, (December 2014), 3-24.

Barnett, J., \& Adger, W. N. (2007). Climate change, human security and violent conflict. Political Geography, 26(6), 639-655. http://doi.org/10.1016/j.polgeo.2007.03.003

Bloom, D. E., Canning, D., \& Fink, G. (2008). Urbanization and the Wealth of Nations. Science (New York, N.Y.), 319(5864), 772-775. http://doi.org/10.1126/science.1153057

Chan, K. W. (2010). Fundamentals of China's Urbanization and Policy, 10(1), 63-94.

Chen, J. M., An, S., Yu, Æ. W., \& Chen, Æ. J. M. (2007). The spatiotemporal dynamics of rapid urban growth in the Nanjing metropolitan region of China . Landscape Ecol in the Nanjing metropolitan region of China, (March 2016). http://doi.org/10.1007/s10980-007-9079-5

China Briefing. (2011). Understanding Development Zones in China - China Briefing News. Retrieved May 2, 2017, from http://www.china-briefing.com/news/2011/10/05/understanding-development-zones-in-china. html 
Cohen, B. (2006). Urbanization in Developing Countries : Current Trends, Future Projections, and Key Challenges for Sustainability Urbanization in developing countries : Current trends, future projections, and key challenges for sustainability, (March). http://doi.org/10.1016/j.techsoc.2005.10.005

Dawn. (2012). Industrialization in Pakistan - Newspaper - DAWN.COM. Retrieved April 28, 2017, from https://www.dawn.com/news/13697

Evans, T. (2015). Meet the Need for Inclusive Urbanization in China: Migrants 'Urban Housing Demand along their Socio-Economic Transition.

Gabriel Domínguez. (2014). Pakistan's urbanization: 'A challenge of great proportions' Asia |DW.COM 30.12.2014. Retrieved April 29, 2017, from http://www.dw.com/en/pakistans-urbanization-a-challenge-of-great-proportions/a-18163731

Gu, C., Wu, L., \& Cook, I. (2012). Progress in research on Chinese urbanization. Frontiers of Architectural Research. Elsevier. http://doi.org/10.1016/j.foar.2012.02.013

Haider, M., Haque, N. U., Tahir, N. H. and A., Iqbal, A., Kugelman, M., Sania Nishtar, Farrukh Chishtie,... Siddiqui, T. (2014). Pakistan's Runaway Urbanization :Hasan, M. (2016). Pakistan faces increasing threats from disasters, warns NDMA report-NewspaperDAWN.COM. Retrieved April 24, 2017, from https://www.dawn.com/news/1266144

He, C., Tian, J., Shi, P., \& Hu, D. (2011). Simulation of the spatial stress due to urban expansion on the wetlands in Beijing, China using a GIS-based assessment model. Landscape and Urban Planning, 101(3), 269-277. http://doi.org/10.1016/j.landurbplan.2011.02.032

$\mathrm{Hu}$, R. (2013). Drivers of China's Urbanisation and Property Development. Australasian Journal of Regional Studies, 19(2), 156-181.

Hull, K. (2009). Understanding the Relationship between Economic Growth , Employment and Poverty Reduction. Promoting Pro-Poor Growth: Employment, (2006), 69-94.

IFRC. (2010). World Disasters Report 2010. International federation of Red Cross and Red crescent Societies. http://doi.org/10.1037/e569662006-003

Jacobson, G. A. Y. N. O. R. I. (1976). The International Migration Factor: Causes and Consequences, $1(2), 1-2$.

Johnson, C. (2010). World Disasters Report 2010. http://doi.org/10.1037/e569662006-003

Kedir, M., Schmidt, E., \& Waqas, A. (2016). Pakistan's Changing Demography : Urbanization and Peri - Urban Transformation Over Time, 39, 1-16.

Klein, M., \& Sauer, A. (2008). Make Your Publication Visible, 63. http://doi.org/10.1007/s10273-011-1262-2

Kniivilä, M. (2007). Industrial Development and Economic Growth: Implications for Poverty Reduction and Income Inequality. In Industrial Development for the 21st Century: Sustainable Development Perspectives (pp. 295-332). Retrieved from http://www.un.org/esa/sustdev/publications/industrial_development/3_1.pdf

Kugelman, M. (2013). NOREF Expert Analysis Urbanisation in Pakistan: causes and consequences, (January).

Liu, S., Li, X., \& Zhang, M. (2003). Scenario Analysis on Urbanization and Rural-Urban Migration in China, (September). 


\section{$\Lambda$ Macrothink}

Journal of Social Science Studies

ISSN 2329-9150

2018, Vol. 5, No. 1

Liu, Y., Wang, L., \& Long, H. (2008). Spatio-temporal analysis of land-use conversion in the eastern coastal China during 1996-2005. Journal of Geographical Sciences, 18(3), 274-282. http://doi.org/10.1007/s11442-008-0274-3

Long, H., Li, Y., Liu, Y., Woods, M., \& Zou, J. (2012). Land Use Policy Accelerated restructuring in rural China fueled by " increasing vs . decreasing balance " land-use policy for dealing with hollowed villages. Land Use Policy, 29(1), 11-22. http://doi.org/10.1016/j.landusepol.2011.04.003

Long, H., Zou, J., \& Liu, Y. (2009). Differentiation of rural development driven by industrialization and urbanization in eastern coastal China. Habitat International, 33(4), 454-462. http://doi.org/10.1016/j.habitatint.2009.03.003

Ma, Z. (1999). Temporary migration and regional development in China. Environment and Planning A, 31(5), 783-802. http://doi.org/10.1068/a310783

Martine, G., \& Alex Marshall. (2007). State of world population 2007: unleashing the potential of urban growth.

Miguel Barrientos. (2015). Pakistan - Net migration rate - Historical Data Graphs per Year. Retrieved April 24, 2017, from http://www.indexmundi.com/g/g.aspx?v=27\&c=pk\&l=en mofcom China. (2017). MINISTRY OF COMMERCE, PEOPLE'S REPUBLIC OF CHINA. Retrieved April 24, 2017, from http://english.mofcom.gov.cn/

Muhammad, A., \& Ishfaq, A. (2011). Industrial development, agricultural growth, urbanization and environmental Kuznets curve in Pakistan. Business, (8225). Retrieved from http://mpra.ub.uni-muenchen.de/33469/

Murtaza Haider, M. G. B. (2010). Urbanization and Local Governance Challenges in Pakistan Environment and Urbanization Asia, (March). http://doi.org/10.1177/097542530900100107

Nadeem, A. (2015). Economic losses from disasters, (ii). Retrieved from https://www.google.com.hk/url?sa=t\&rct=j\&q=\&esrc=s\&source=web\&cd=3\&cad=rja\&uact $=8 \&$ ved $=0$ ahUKEwiVrpb38bzTAhXDGpQKHUZjCK4QFggsMAI\&url $=$ http $\% 3 \mathrm{~A} \% 2 \mathrm{~F} \% 2 \mathrm{Fw}$ ww.lead.org.pk\%2Flead\%2Fattachments\%2Fbriefings\%2FLPNB3.pdf\&usg=AFQjCNG9-Q WJxuc6um8H6fi0d_AmQ_tfBQ

Naphade, M., Banavar, G., Harrison, C., Paraszczak, J., \& Morris, R. (2011). Smarter cities and their innovation challenges. Computer, 44(6), 32-39. http://doi.org/10.1109/MC.2011.187

Nasira Jabeen, Umm-e- Farwa, Z. I. J. (2015). Urbanization in Pakistan: A Governance Perspective.

Nasira Jabeen, Umm-e- Farwa, Z. I. J. (2016). Urbanization in Pakistan : A Governance Perspective, (January).

PBS, P. (2016). P S L M - 2014-15 Pakistan Social and Living Standards Measurement. Perception. Islamabad. Retrieved from http://www.pbs.gov.pk/content/pakistan-social-and-living-standards-measurement

Porter, M. E., Stern, S., \& Artavia Loría, R. (2015). Social Progress Index 2015, 153.

Raleigh, C., Jordan, L., \& Salehyan, I. (2008). Assessing the Impact of Climate Change on Migration and Conflict. World, 24, 1-57. Retrieved from http://siteresources.worldbank.org/EXTSOCIALDEVELOPMENT/Resources/SDCCWorkin 
gPaper_MigrationandConflict.pdf

Rayhan, G. (2007). Coping with Floods: Does Rural-Urban Migration Play any Role for Survival in rural Bangladesh? Journal of Identity and Migration Studies, 1(2), 82-98. http://doi.org/10.1007/978-3-319-10127-9

Saunders, M., Lewis, P., \& Thornhill, A. (2009). Research Methods for Business Students. Research methods for business students. http://doi.org/10.1007/s13398-014-0173-7.2

SBP. (2017). State Bank of Pakistan. Retrieved April 24, 2017, from http://www.sbp.org.pk/

Shen, L., Cheng, S., \& James, A. (2005). Urbanization , sustainability and the utilization of energy and mineral resources in China, 22(4), 287-302. http://doi.org/10.1016/j.cities.2005.05.007

Shin, H. B. (2015). Urbanization in China Urbanization in China, (1), 1-19.

SPDC, S. P. and D. C. (2001). SOCIAL.

Surveys, O. E. (2015). OECD Economic Surveys 中国经济调查. Africa, 2010(July), 1-128. http://doi.org/10.1787/eco_surveys-jpn-2009-en

Tan, M., Tan, M., Li, X., Xie, H., \& Lu, C. (2005). Urban land expansion and arable land loss in China-A case study of Beijing-Tianjin-Hebei region Urban land expansion and arable land loss in China - a case study, (JULY). http://doi.org/10.1016/j.landusepol.2004.03.003

The EM-DAT. (2017). PAKISTAN and CHINA- Countries comparison. Retrieved April 24, 2017, from http://www.emdat.be/country_profile/index.html

The World Bank. (2016). World Development Report 2016: Digital Dividends. Main Messages. Journal of Chemical Information and Modeling, 53. http://doi.org/10.1596/978-1-4648-0671-1

Thrift, N. (2012). The Pull of Cities - WorldWise - The Chronicle of Higher Education The Pull of Cities-WorldWise-The Chronicle of Higher Education, 1-2. Retrieved from http://www.chronicle.com/blogs/worldwise/the-pull-of-cities/29096

UNDP. (2017). Human Development Reports. Retrieved April 24, 2017, from http://hdr.undp.org/en/countries/profiles

UNIDO. (2015). Economic Zones in the Asean, (August).

United Nations. (2011). World Urbanization Prospects The 2011 Revision.

United Nations. (2014). World Urbanization Prospects.

United Nations Environment Programme [UNEP]. (2005). GEO Year Book 2004/5: An Overview of Our Changing Environment. Retrieved from http://www.unep.org/yearbook/2004/pdf/geo_yearbook_2004.pdf

Vidová, J. (2010). Industrial parks-history, their present and influence on employment. Národohospodářsky Obzor, $\quad X(1), \quad 41-58 . \quad$ Retrieved from http://is.muni.cz/do/1456/soubory/aktivity/obzor/6182612/12878341/Industrial_parks_-_histo ry_their_present_and_influence_on_employment.pdf

Wei, Y. H. D. (2007). Regional Development in China: Transitional Institutions. Embedded Globalization, and Hybrid Economies, (1), 16-36.

Wenze, Y., \& Yong, Liu, P. F. (2013). Measuring Urban Sprawl and Its Drivers in Large 
Chinese Cities: The Case of Hangzhou, (MARCH). http://doi.org/10.1016/j.landusepol.2012.07.018

Weziak-Bialowolska, D. (2016). Quality of life in cities - Empirical evidence in comparative European perspective. Cities, 58, 87-96. http://doi.org/10.1016/j.cities.2016.05.016

World Bank. (2016). Indicators Data. Retrieved April 24, 2017, from http://data.worldbank.org/indicator

Wu, J., \& Hobbs, R. (2002). Key issues and research priorities in landscape ecology : An idiosyncratic synthesis, (1999), 355-365.

Wu, W., Zhao, S., Zhu, C., \& Jiang, J. (2015). A comparative study of urban expansion in Beijing, Tianjin and Shijiazhuang over the past three decades. Landscape and Urban Planning, 134(February 2016), 93-106. http://doi.org/10.1016/j.landurbplan.2014.10.010

Xiao, J., Shen, Y., Ge, J., Tateishi, R., \& Tang, C. (2006). Evaluating urban expansion and land use change in Shijiazhuang, China, by using GIS and remote sensing, 75, 69-80. http://doi.org/10.1016/j.landurbplan.2004.12.005

Xibo, W., \& Zaigao, Y. (2011). The Concept of Smart City and Future City Development Urban Studies. Retrieved from http://en.cnki.com.cn/Article_en/CJFDTOTAL-CSFY201011011.htm

Zhou, J., Zhang, X., \& Shen, L. (2015). Urbanization bubble: Four quadrants measurement model. Cities, 46, 8-15. http://doi.org/10.1016/j.cities.2015.04.007

Zhu, Y. (2015). MIGRATION, (December 2014).

Zhu, Y., \& Chen, W. (2010). The Settlement Intention of China's, 267(March 2009), 253-267.

\section{Copyright Disclaimer}

Copyright for this article is retained by the author(s), with first publication rights granted to the journal.

This is an open-access article distributed under the terms and conditions of the Creative Commons Attribution license (http://creativecommons.org/licenses/by/3.0/). 